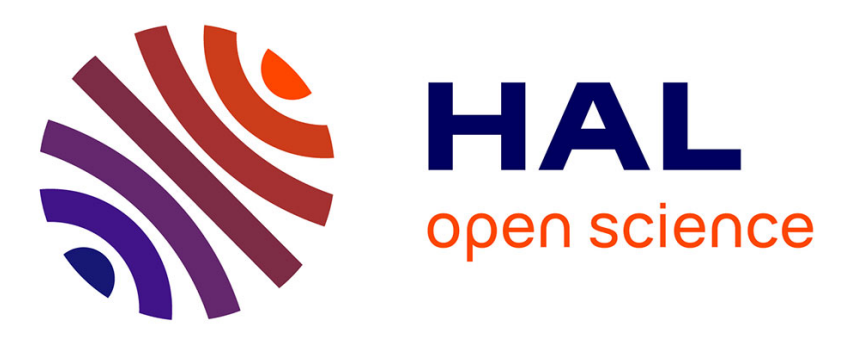

\title{
Oxygen-reducing biocathodes designed with pure cultures of microbial strains isolated from seawater biofilms
}

Sandra Debuy, Sophie Pécastaings, Alain Bergel, Benjamin Erable

\section{- To cite this version:}

Sandra Debuy, Sophie Pécastaings, Alain Bergel, Benjamin Erable. Oxygen-reducing biocathodes designed with pure cultures of microbial strains isolated from seawater biofilms. International Biodeterioration and Biodegradation, 2015, vol. 103, pp. 16-22. 10.1016/j.ibiod.2015.03.028 . hal-01149815

\author{
HAL Id: hal-01149815 \\ https://hal.science/hal-01149815
}

Submitted on 7 May 2015

HAL is a multi-disciplinary open access archive for the deposit and dissemination of scientific research documents, whether they are published or not. The documents may come from teaching and research institutions in France or abroad, or from public or private research centers.
L'archive ouverte pluridisciplinaire $\mathbf{H A L}$, est destinée au dépôt et à la diffusion de documents scientifiques de niveau recherche, publiés ou non, émanant des établissements d'enseignement et de recherche français ou étrangers, des laboratoires publics ou privés. 


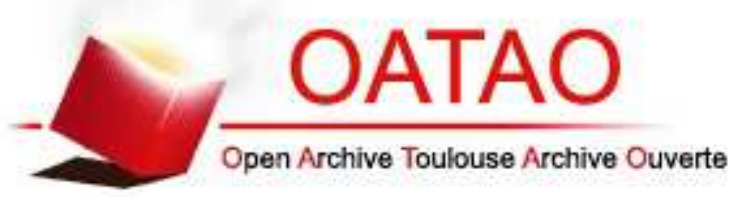

\section{Open Archive TOULOUSE Archive Ouverte (OATAO)}

OATAO is an open access repository that collects the work of Toulouse researchers and makes it freely available over the web where possible.

This is an author-deposited version published in : http://oatao.univ-toulouse.fr/ Eprints ID : 13881

To link to this article : DOI:10.1016/j.ibiod.2015.03.028

URL : http://dx.doi.org/10.1016/j.ibiod.2015.03.028

\section{To cite this version :}

Debuy, Sandra and Pécastaings, Sophie and Bergel, Alain and

Erable, Benjamin Oxygen-reducing biocathodes designed with pure cultures of microbial strains isolated from seawater biofilms. (2015) International Biodeterioration \& Biodegradation, vol. 103. pp. 1622. ISSN 0964-8305

Any correspondance concerning this service should be sent to the repository administrator: staff-oatao@ listes-diff.inp-toulouse.fr 


\title{
Oxygen-reducing biocathodes designed with pure cultures of microbial strains isolated from seawater biofilms
}

\author{
Sandra Debuy ${ }^{\mathrm{a},{ }^{*}}$, Sophie Pecastaings ${ }^{\mathrm{b}}$, Alain Bergel ${ }^{\mathrm{a}}$, Benjamin Erable ${ }^{\mathrm{a}}$ \\ a Laboratoire de Génie Chimique, CNRS-Université de Toulouse (INPT), 4 allée Emile Monso, 31432 Toulouse, France \\ ${ }^{\mathrm{b}}$ Université de Toulouse, UPS, Laboratoire de Génie Chimique, Faculté de Pharmacie, 35, chemin des Maraîchers, 31062 Toulouse, France
}

Keywords:

Biocathode

Oxygen reduction

Marine bacteria

Microbial fuel cel

Gamma-Proteobacteria

\begin{abstract}
A B S T R A C T
Microbial biofilms that form on metallic surfaces in natural seawater are known to generate efficient oxygen-reducing cathodes. The microbial catalysis of oxygen reduction is a major mechanism of corrosion in marine aerobic environments; it can also be exploited to develop biocathodes for microbial fuel cells. In the latter case, seawater biocathodes have the great advantage of operating in high-salinity electrolytes. Four bacterial strains (Pseudoalteromonas sp., Marinobacter sp., Roseobacter sp., Bacillus sp.) were isolated from an oxygen-reducing biocathode formed in natural seawater. 16S rDNA pyrosequencing analysis showed that the strains isolated were representative of the microbial community that composed the initial multispecies biocathode, which was dominated by Gamma-Proteobacteria. Each strain was able to form oxygen-reducing monospecies biocathodes both in natural seawater and in a synthetic medium with the same salinity. Stable current densities of $40 \mathrm{~mA} \mathrm{~m}{ }^{-2}$ were produced under constant applied potential $(-0.30 \mathrm{~V} / \mathrm{SCE})$ and up to $0.8 \mathrm{~A} \mathrm{~m}^{-2}$ was recorded at $-0.60 \mathrm{~V} / \mathrm{SCE}$. This work provides the first description of monospecies biocathodes designed with salinity-tolerant strains and offers an experimental model to advance the investigation of the microbiological and biochemical processes on seawater biocathodes in well-controlled conditions.
\end{abstract}

\section{Introduction}

The microbial biofilms that spontaneously develop on the surface of metallic materials immersed in aerated seawater play an essential role in their corrosion (Mollica, 1992). It has been known for some decades that such biofilms can catalyse the reaction of oxygen reduction on the material surface and thus drastically enhance the cathodic branch of corrosion processes, particularly on stainless steels. The precise mechanism of $\mathrm{O}_{2}$-reduction catalysis has not yet been fully deciphered, although several different pathways have been investigated with some success (Landoulsi et al., 2008; Erable et al., 2012).

On the other hand, the same type of seawater biofilms can efficiently catalyse oxygen reduction in fuel cells. Microbial biocathodes formed in aerated seawater have been successfully implemented as cathodes of microbial fuel cells (MFCs) (Bergel et al., 2005). MFCs are an appealing technology that can transform directly into electricity the chemical energy contained in a

\footnotetext{
* Corresponding author.

E-mail address: sandra.debuy@ensiacet.fr (S. Debuy).
}

large variety of low cost organic compounds (Pant et al., 2010). Impressive proofs of concept have been reported for several years with small cells (Liu et al., 2008; Pocaznoi et al., 2012) but the objective to scale up to large size applications is still challenging. The electrolytes used in MFCs have low ionic conductivity, generally less than $2 \mathrm{~S} \mathrm{~m}^{-1}$ (Logan and Rabaey, 2012; Pocaznoi et al., 2012; Rousseau et al., 2013). For comparison, conventional electrolytes that are used in commercial, abiotic electrochemical reactors have conductivities of several tens of $\mathrm{S} \mathrm{m}^{-1}$ (e.g. $\mathrm{KOH} 33 \%$ by mass used for water electrolysis has a conductivity of $60 \mathrm{~S} \mathrm{~m}^{-1}$ ). In the case of microbial electrochemical systems, it is not possible to increase the conductivity of the electrolytes to any great extent because many microorganisms are sensitive to osmotic pressure and consequently do not accept high salt concentrations. (Lefebvre et al., 2012) have shown that the power produced by an MFC increases for up to $\mathrm{NaCl}$ concentrations of $20 \mathrm{~g} \mathrm{~L}^{-1}$, but a further rise of $\mathrm{NaCl}$ to $40 \mathrm{~g} \mathrm{~L}^{-1}$ results in a decrease of $50 \%$ in power output because of degradation of the bioanode kinetics. Hence, most MFCs have been developed with electrolytes with low conductivities (except in the particular case of benthic MFCs) and the resulting high internal cell resistance of the cell is a major drawback in MFC development. 
Recently, promising salinity-tolerant microbial anodes have opened up the way to higher conductivities, providing up to $80 \mathrm{~A} \mathrm{~m}^{-2}$ at salinities comparable to that of seawater $\left(45 \mathrm{~g} \mathrm{~L}^{-1} \mathrm{NaCl}\right)$ and conductivity of $10.4 \mathrm{~S} \mathrm{~m}^{-1}$ (Rousseau et al., 2014). Such bioanodes would now allow the internal resistance of MFCs to be considerably decreased, provided that they were associated with cathodes able to operate at similar salinities. Using abiotic cathodes, which are not sensitive to salinity, may be one solution. Nevertheless, the inorganic catalysts of oxygen reduction, such as platinum, give poor performance at the neutral $\mathrm{pH}$ required in MFCs.

For instance, it has been shown that, in the long term, the biofilm that develops on graphite cathodes significantly increases their kinetic efficiency and graphite platinum-free cathodes have led to MFCs with performance similar to those with graphite platinumloaded cathodes (Cristiani et al., 2013a). In this case, the biofouling that develops on the cathode surface has proven to be as efficient as the platinum used to design abiotic air-cathodes. Microbial biocathodes consequently remain worthwhile solutions for designing MFCs. The association of the newly discovered salinitytolerant microbial anodes with microbial cathodes able to operate in seawater may be a promising solution for the design of MFCs with low internal resistance.

Unfortunately, it remains difficult to set up microbial biocathodes far from the sea (Faimali et al., 2010). It has been possible to reconstruct them in the laboratory (Erable et al., 2010) but the process requires fresh natural seawater. The mechanisms of electron transfer remain poorly understood, in part because of the complex multispecies nature of the electroactive biofilm (Faimali et al., 2010; Vandecandelaere et al., 2010) and because of the lack of a simple experimental model. In the domain of microbial corrosion of steels, a monospecies model has been implemented in river waters with Leptothrix discophora (Shi et al., 2002). It was thus confirmed that cycling of manganese ions may be an important pathway of oxygen reducing catalysis, particularly in waters that contain a high concentration of manganese ions (Braughton et al., 2001). The same experimental model was then proposed to design MFC biocathodes (Rhoads et al., 2005). Such a monospecies model is essential to progress in the basic understanding and technological mastery of oxygen-reducing biofilms, because it focuses on a single aspect of the multiple, intricate pathways of oxygen reduction that occur in natural biocathodes. Using a pure culture ensures fair reproducibility of the results with the possibility of multiplying the experiments in well-controlled laboratory conditions. It is thus possible to characterize a given pathway in depth and, in the case of an MFC biocathode, to boost it to its maximum performance. In the sister case of microbial anodes, the possibility of multiplying experiments with pure cultures of Geobacter sulfurreducens or Shewanella sp. has been a powerful experimental tool that has boosted important fundamental advances (for reviews see Bonanni et al., 2012; Malvankar and Lovley, 2012; Rimboud et al., 2014). Such a possibility does not exist for seawater biocathodes yet.

Several attempts have been made to isolate electroactive strains from seawater biofilms in order to design monospecies biocathodes. Surprisingly, many strains have revealed some ability to catalyse $\mathrm{O}_{2}$ reduction when measured by cyclic voltammetry but none of them has been able to form an efficient monospecies biocathode under constant applied potential. The presence of the microbial cells significantly shifted the current peak of oxygen reduction towards less negative potentials and increased the maximum transient currents (Parot et al., 2011). To our knowledge, only two strains isolated from a seawater biofilm have produced stable current under constant applied potential, but the current density was very low, less than $1 \mathrm{~mA} \mathrm{~m}^{-2}$ (Erable et al., 2010). With the exception of these two poor-efficiency biocathodes, no monospecies $\mathrm{O}_{2}$-reducing biocathode able to operate at high salinity has been reported so far.

The objective of the present work was to isolate pure strains from seawater multispecies biofilms to design monospecies $\mathrm{O}_{2}$ reducing biocathodes able to operate at seawater salinity. It has been reported that heterotrophic bacteria make up the majority of the microbial community that composes biofilms formed in seawater when it contains organic compounds (Heip et al., 1995) as is the case in harbours. Moreover, heterotrophs generally grow faster than autotrophs, which should be a considerable advantage to reduce the time of biocathode formation.

\section{Materials and methods}

\section{Multispecies biocathode formation on site}

The initial multispecies biocathodes were formed on stainless steel electrodes (UNS S31254: Cr 19.5-20.5\%, Ni 17.5-18.5\%, Mo 6-6.5\%, N 0.18-0.22\%, Cu 0.5-1\%, S $<0.01 \%$, Si $<0.8 \%$, P $<0.03 \%$, $\mathrm{Mn}<1 \%, \mathrm{C}<0.02 \%$, Fe balance) immersed in a tank filled with continuously renewed seawater from Genoa harbour (Italy). Biocathodes were formed under constant polarization at $-0.20 \mathrm{~V} / \mathrm{SCE}$ for several days and collected when a stable current density in the $200-400 \mathrm{~mA} \mathrm{~m} \mathrm{~m}^{-2}$ range was obtained (Bergel et al., 2005). The biocathodes were stored at $4{ }^{\circ} \mathrm{C}$ in seawater before being used. The multispecies biocathodes were placed in a Petri dish and the biofilm was removed from the electrode by scraping in $5 \mathrm{ml}$ of sterile synthetic seawater. The biofilm samples were then used to isolate heterotrophic aerobic bacteria.

\section{Isolation and identification of heterotrophic bacteria}

Two different recovery media were used to grow the bacteria using the initial biofilm as inoculum: either plates of Marine Agar (MA, Difco Laboratories, Detroit, Mich.) or plates of synthetic seawater (standard ASTM D1141-90) (agar 7\%) supplemented with $1 \mathrm{~g} \mathrm{~L}^{-1}$ of glucose as a carbon source. Cultures were performed at $30^{\circ} \mathrm{C}$. Microorganisms collected from the plates were then cultured in liquid medium (marine broth (Difco) diluted 3 times) and finally stored at $-20^{\circ} \mathrm{C}$ in the same medium supplemented with $20 \%$ (v/v) glycerol.

DNA was extracted from four microbial colonies collected on Marine Agar plates using the MOBIO PowerSoil ${ }^{\circledR}$ DNA Isolation kit, according to the manufacturer's instructions. DNA concentrations were checked by reading the absorbance at $260 \mathrm{~nm}$. As these concentrations were too low, DNA amplification was performed by PCR with $16 \mathrm{~S}$ universal primers p8fpl (5' AGA GTT TGA TCC TGG CTC AG 3') and p806R (5' GGA CTA CCA GGG TAT CTA AT $3^{\prime}$ ) (Invitrogen TM) (McCabe et al., 1999). PCR reaction was performed in a final volume of $50 \mu \mathrm{L}$ with $0.25 \mu \mathrm{L}$ of GoTaq ${ }^{\circledR}$ DNA polymerase (Promega), $5 \mu \mathrm{L}$ of forward and reverse primers, $10 \mu \mathrm{L}$ of GoTaq Reaction buffer (Promega), $1 \mu \mathrm{L}$ of nucleotide mix (Promega), $10 \mu \mathrm{L}$ of DNA template, and $18.75 \mu \mathrm{L}$ of nuclease free water. The PCR protocol was: initial denaturation $\left(95{ }^{\circ} \mathrm{C}\right.$ for $4 \mathrm{~min}$ ), denaturation $\left(94^{\circ} \mathrm{C}\right.$ for $\left.1 \mathrm{~min}\right)$, annealing $\left(55^{\circ} \mathrm{C}\right.$ (McCabe et al., 1999) for $2 \mathrm{~min}, 30$ cycles), extension $\left(72{ }^{\circ} \mathrm{C}\right.$ for $2 \mathrm{~min}$ ) and final extension $\left(72^{\circ} \mathrm{C}\right.$ for $10 \mathrm{~min}$ ) (Recommended Thermal Cycling Conditions for GoTaq ${ }^{\circledR}$ DNA Polymerase). The samples were sent to Eurofins Company where 16S rDNA gene sequencing (Sanger technique) was performed. Once sequencing was completed, data were analysed using BLASTn (NCBI website) for the genus identification. 
Formation and characterization of monospecies biocathodes

Each strain was grown in marine broth that was diluted 3 times and inoculated at $10 \%$ from the frozen bacterial stock. After 3 days' growth at $30{ }^{\circ} \mathrm{C}$ and $150 \mathrm{rpm}$, a clean stainless steel electrode $\left(2 \times 10 \mathrm{~cm}^{2}\right.$ geometric surface area) was immersed in $50 \mathrm{ml}$ of culture for $1 \mathrm{~h}$, and then transferred into the sterilized electrochemical reactor containing $500 \mathrm{ml}$ of filtered natural seawater ( $0.2 \mu \mathrm{m}$ filter) or synthetic seawater, $\mathrm{pH}$ 8.0. Synthetic seawater was composed of $24.53 \mathrm{~g} / \mathrm{L}$ of $\mathrm{NaCl}, 5.2 \mathrm{~g} / \mathrm{L}$ of $\mathrm{MgCl}_{2}, 4.09 \mathrm{~g} / \mathrm{L}$ of $\mathrm{Na}_{2} \mathrm{SO}_{4}$, $1.16 \mathrm{~g} / \mathrm{L}$ of $\mathrm{CaCl}_{2}, 0.695 \mathrm{~g} / \mathrm{L}$ of $\mathrm{KCl}, 0.201 \mathrm{~g} / \mathrm{L}$ of $\mathrm{NaHCO}_{3}, 0.101 \mathrm{~g} / \mathrm{L}$ of $\mathrm{KBr}, 0.027 \mathrm{~g} / \mathrm{L}$ of $\mathrm{H}_{3} \mathrm{BO}_{3}, 0.025 \mathrm{~g} / \mathrm{L}$ of $\mathrm{SrCl}_{2}$ and $0.003 \mathrm{~g} / \mathrm{L}$ of $\mathrm{NaF}$ (ASTM D1141-90). The reactors were inoculated with $50 \mathrm{ml}$ of the culture. A saturated calomel electrode (SCE, Radiometer, $+0.24 \mathrm{~V} /$ SHE) was used as the reference and a platinum grid as the auxiliary electrode. The bulk was continuously stirred with a magnetic stirrer (300 rpm) and air was bubbled into the solution when indicated. The reactors were immersed in a thermostated bath at $30^{\circ} \mathrm{C}$. The potential of $-0.20 \mathrm{~V} / \mathrm{SCE}$ or $-0.30 \mathrm{~V} / \mathrm{SCE}$, as indicated in the text, was applied using a multichannel potentiostat (Biologic, France, ECLab software). The chronoamperometry was interrupted to record cyclic voltammetry at $1 \mathrm{mV} \mathrm{s}^{-1}$ by scanning the potential from the polarization value to $0.30 \mathrm{~V} / \mathrm{SCE}$ (upper limit) and back down to $-0.70 \mathrm{~V} / \mathrm{SCE}$ (lower limit).

\section{Epifluorescent imaging}

Electrodes were extracted from the reactors and washed carefully with sterile seawater to remove all materials except the attached biofilms. Biocathodes were stained with $0.03 \%$ acridine orange (A6014, Sigma) for $10 \mathrm{~min}$, rinsed with sterile seawater and then left to dry in ambient air. Biofilms were imaged with a Carl Zeiss Axio Imager-M2 microscope equipped for epifluorescence with an HXP $200 \mathrm{C}$ light source and the Zeiss 09 filter (excitor HP450 - 490, reflector FT 10, barrier filter LP520). Images were acquired with a digital camera (Zeiss AxioCam MRm) and the biofilm coverage ratios were assessed with the AxioVision software. For each biocathode, the biofilm coverage ratio was calculated on a spot that was representative of the colonization observed at various locations of the electrode surface.

\section{Results and discussion}

\section{Isolation of heterotrophic bacteria from marine electroactive biofilm}

The initial $\mathrm{O}_{2}$-reducing multispecies biocathode was formed directly in the Mediterranean Sea in Genoa harbour. The multispecies biofilm was collected from the biocathodes and used to inoculate both marine agar (MA) plates and plates of synthetic seawater supplemented with $1 \mathrm{~g} \mathrm{~L}^{-1}$ glucose. Only four colonies with different visual appearances were obtained in both cases. They were harvested and individually cultured in solution to be used to design monospecies biocathodes. 16S rDNA sequencing confirmed that each colony harvested from the plates was composed of a single strain, which was then identified. Four isolates were thus obtained: three belonged to the Proteobacteria phylum, including two Gamma-Proteobacteria (Pseudoalteromonas sp. and Marinobacter sp) and one Alpha-Proteobacteria (Roseobacter sp.), and the fourth belonged to the Firmicutes phylum (Bacillus sp.). These results were fully consistent with previous studies showing the dominance of Gamma- and AlphaProteobacteria and also the presence of Firmicutes in the cultivable microbial fraction of similar $\mathrm{O}_{2}$-reducing biocathodes formed from seawater (Holmes et al., 2004; Vandecandelaere et al., 2010).
Electroactivity of the isolated strains

The electroactivity of the isolates was checked with stainless steel cathodes polarized at $-0.20 \mathrm{~V} / \mathrm{SCE}$ in filtered natural seawater. All the isolates produced stable current densities in the $0.5-2 \mathrm{~mA} \mathrm{~m}^{-2}$ range (Table 1 ). A previous study of 19 strains isolated from a similar seawater $\mathrm{O}_{2}$-reducing biocathode reported similar current densities of -0.4 and $-1 \mathrm{~mA} \mathrm{~m}^{-2}$ but for only two isolates (Acinetobacter johsonii and Winogradskyella poriferorum), while the others did not give any current (Erable et al., 2010). Here, the isolation procedure led to only 4 strains but each revealed its ability to catalyse $\mathrm{O}_{2}$-reduction. After 14 days, the polarization was changed to $-0.30 \mathrm{~V} / \mathrm{SCE}$ and the current density increased immediately by a factor of $4-10$. A maximum of $15 \mathrm{~mA} \mathrm{~m}^{-2}$ was produced by the Pseudoalteromonas sp.

Similar experiments were reproduced in filtered natural seawater and in synthetic seawater, but starting the polarization directly at $-0.30 \mathrm{~V} / \mathrm{SCE}$. Each strain produced significant current densities of up to $40 \mathrm{~mA} \mathrm{~m}^{-2}$ (Table 1) which decreased drastically when stirring was stopped. For instance, during the 3rd assay in sterile natural seawater, the reduction current densities above $30 \mathrm{~mA} \mathrm{~m}^{-2}$ (in absolute value) displayed by the three strains decreased to around $10 \mathrm{~mA} \mathrm{~m}{ }^{-2}$ in the absence of stirring. The current was limited by oxygen transfer to the electrode surface, which was significantly slower in a quiescent solution. In contrast, aeration of the reactors by air bubbling significantly increased the current densities as shown, for instance, on cyclic voltammetries (Fig. 2), which confirmed that the current value was controlled by oxygen transfer. Surprisingly, the current started as soon as the polarization was established (Fig. 1) while, more generally, the current would be expected to start from zero and increase gradually with time. Here, in contrast, the current was maximum since the beginning of polarization (e.g. Bacillus, Marinobacter and Pseudoalteromonas sp. in Fig. 1) or represented a considerable percentage of the maximum (e.g. around $60 \%$ of the maximum for Roseobacter sp. in Fig. 1).

The main difference in the present protocol with respect to the previous study was the preliminary immersion of the clean electrode in the bacterial suspension before transferring it into the electrochemical reactor. This step was not present in the previous studies. It seems probable that, thanks to this preliminary step, microbial cells were present on the electrode surface from the beginning of the electrochemical experiments. This supplementary step explained why the strains were able to produce current from the beginning of polarization. The initial adhesion of the bacterial cells to the electrode surface is consequently a crucial step in the formation of monospecies biocathodes. The small increase in current during 14 days of polarization (Fig. 1) indicated that the current was due to the initial adhesion of the cells during the preliminary immersion of the clean electrode in the bacterial suspension and not to gradual microbial colonization of the surface during the electrochemical experimentation.

At the end of the experiments, the microbial colonization of the electrode surfaces was always low, with biofilm coverage ratios from 7 to $25 \%$, as determined by epifluorescent microscopy for the biocathodes formed in synthetic seawater (1st experiment in Table 1, Fig. 3). There was no straightforward correlation between the biofilm coverage ratio and the current density provided by the biocathodes. Nevertheless, the lowest current density, which was observed with the Roseobacter sp. $\left(0.5 \mathrm{~mA} \mathrm{~m}^{-2}\right)$ in this experiment, corresponded to the lowest coverage ratio (7\%). The other three biocathodes provided current densities from 3 to $35 \mathrm{~mA} \mathrm{~m}^{-2}$ with biofilm coverage ranging from 15 to $25 \%$. Moreover, in this group, the highest current density $\left(35 \mathrm{~mA} \mathrm{~m}^{-2}\right.$ ) was provided by the Marinobacter biocathode, which showed a different biofilm 
Table 1

Performance of the bacterial strains isolated from a multispecies seawater biofilm.

\begin{tabular}{|c|c|c|c|c|c|c|}
\hline & \multicolumn{4}{|c|}{ Natural filtered seawater } & \multicolumn{2}{|c|}{ Synthetic seawater } \\
\hline & \multicolumn{2}{|l|}{$\begin{array}{l}\text { 1st Assay } \\
\mathrm{mA} \mathrm{m}^{-2}\end{array}$} & \multirow{2}{*}{$\begin{array}{l}\text { 2nd Assay } \\
\frac{\mathrm{mA} \mathrm{m}^{-2}}{-0.3 \mathrm{~V} / \mathrm{ref}}\end{array}$} & \multirow{2}{*}{$\begin{array}{l}\begin{array}{l}\text { 3rd Assay } \\
\mathrm{mA} \mathrm{m}{ }^{-2}\end{array} \\
-0.3 \mathrm{~V} / \mathrm{ref}\end{array}$} & \multirow{2}{*}{$\begin{array}{l}\text { 1st Assay } \\
\frac{\mathrm{mA} \mathrm{m}^{-2}}{-0.3 \mathrm{~V} / \mathrm{ref}}\end{array}$} & \multirow{2}{*}{$\begin{array}{l}\text { 2nd Assay } \\
\frac{\mathrm{mA} \mathrm{m}^{-2}}{-0.3 \mathrm{~V} / \mathrm{re}}\end{array}$} \\
\hline & $-0.2 \mathrm{~V} / \mathrm{ref}$ & $-0.3 \mathrm{~V} / \mathrm{ref}$ & & & & \\
\hline Control & 0 & 0 & 0 & 0 & 0 & 0 \\
\hline Pseudoalteromonas & 2 & 30 & 5 & 5 & 3 & 4 \\
\hline Bacillus & 0.5 & 5 & 5 & 40 & 3.5 & 10 \\
\hline Marinobacter & 1 & 4 & 5 & 40 & 35 & 8 \\
\hline Roseobacter & 1 & 5 & 30 & 35 & 0.5 & 4 \\
\hline
\end{tabular}

Stable current densities obtained with monospecies biocathodes formed with marine bacteria grown on stainless steel electrodes polarized at - $0.3 \mathrm{~V} / \mathrm{SCE}$, except for the $1 \mathrm{st}$ assay, in which biocathodes were formed at $-0.2 \mathrm{~V} / \mathrm{SCE}$ for 14 days and then switched to $-0.3 \mathrm{~V} / \mathrm{SCE}$. Solutions were continuously stirred with a magnetic barrel ( 300 rpm) without air bubbling.

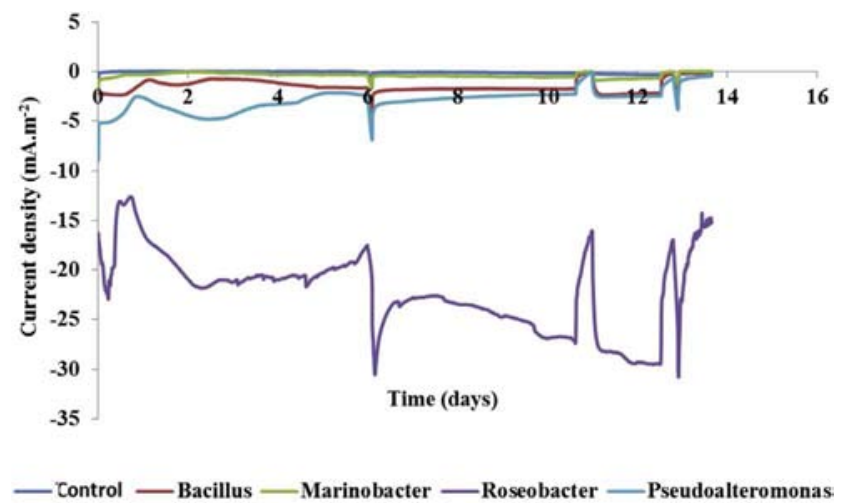

Fig. 1. Chronoamperometry in filtered natural seawater of the bacterial strains isolated from a multispecies seawater biofilm. Stainless steel electrodes were polarized at $-0.3 \mathrm{~V} / \mathrm{SCE}$ during 14 days. The perturbations observed around days 6,11 and 13 were due to $\mathrm{CV}$ recording.

structure. The Marinobacter biocathode was composed of large colonization patches, while the Bacillus and Pseudoalteromonas biocathodes showed only small micro-colonies or single cells scattered on the electrode surface. The biofilm coverage ratio and the biofilm structure affected the current density provided by the biocathodes.

The catalytic effect was fairly efficient compared to the low coverage ratios measured. A previous study carried out on natural marine biofilms developed on stainless steel showed that biofilm coverages around $1-5 \%$ were sufficient to detect, at open circuit, the potential ennoblement due to oxygen reduction catalysis (Mattila et al., 1997). The monospecies biocathodes formed here confirmed that low colonization ratios could induce a significant catalytic effect.
The scattered micro-colonies or single cells suggest that electrode colonization was mainly due to the initial adhesion of the cells from the cell culture rather than the development of a biofilm on the electrode surface during the polarization time. Electrode immersion in the cell culture was fundamental to obtaining current with pure strains extracted from a seawater biofilm. The poor reproducibility of the current densities observed between the replicates that were performed in strictly identical conditions (Table 1) was probably due to the poor control of this first adhesion step. Conversely, the failure of the polarization experiments in previous studies (Erable et al., 2010; Parot et al., 2011), which did not involve the preliminary adhesion from a concentrated cell culture, can now be attributed to the difficulty in colonizing the electrode surface from the diluted inoculum.

The set of 20 independent experiments reported in Table 1 show clear general trends. Firstly, the biocathodes formed at $-0.20 \mathrm{~V} / \mathrm{SCE}$ gave lower currents when switched to $-0.30 \mathrm{~V} / \mathrm{SCE}$ (average current density $7.2 \mathrm{~mA} \mathrm{~m}^{-2}$ ) than the biocathodes formed directly at $-0.30 \mathrm{~V} / \mathrm{SCE}$ (average current density $20.5 \mathrm{~mA} \mathrm{~m}^{-2}$ in the same medium). The biocathodes formed at $-0.30 \mathrm{~V} / \mathrm{SCE}$ were more efficient than those formed at $-0.20 \mathrm{~V} / \mathrm{SCE}$. The polarization potential used during the biocathode formation is consequently an important parameter that directly impacts its electrochemical capability.

Secondly, the results show that artificial seawater gave lower current densities than natural seawater (on average, $6.4 \mathrm{~mA} \mathrm{~m}^{-2} \mathrm{vs}$. $20.5 \mathrm{~mA} \mathrm{~m}^{-2}$ ) but, to our knowledge, this is the first time that microbial strains have revealed the ability to catalyse $\mathrm{O}_{2}$ reduction in synthetic seawater. Although current densities are still modest, the possibility of designing monospecies biocathodes in synthetic seawater is a considerable advance in the development of $\mathrm{O}_{2-}$ reducing biocathodes operating at high salinities, mainly because it offers a well-controlled system in which fundamental
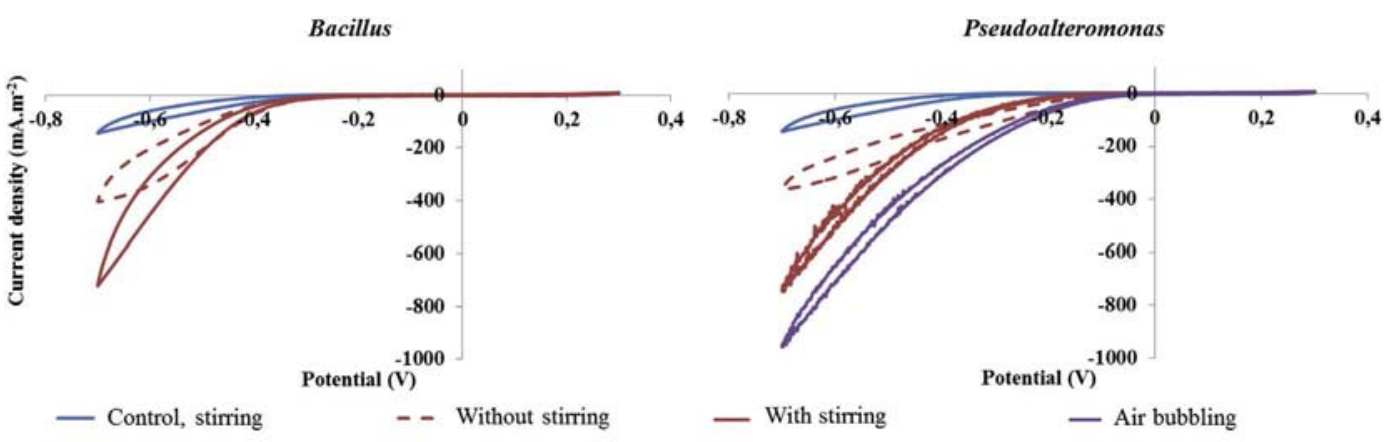

Fig. 2. Cyclic Voltammetry in filtered natural seawater of the bacterial strains isolated from a multispecies seawater biofilm. Cyclic voltammetry was performed at $1 \mathrm{mV} \mathrm{s}{ }^{-1}$ in the range -0.7 to $0.4 \mathrm{~V} / \mathrm{SCE}$ with stirring, without stirring, and with air bubbling for Pseudoalteromonas only. 


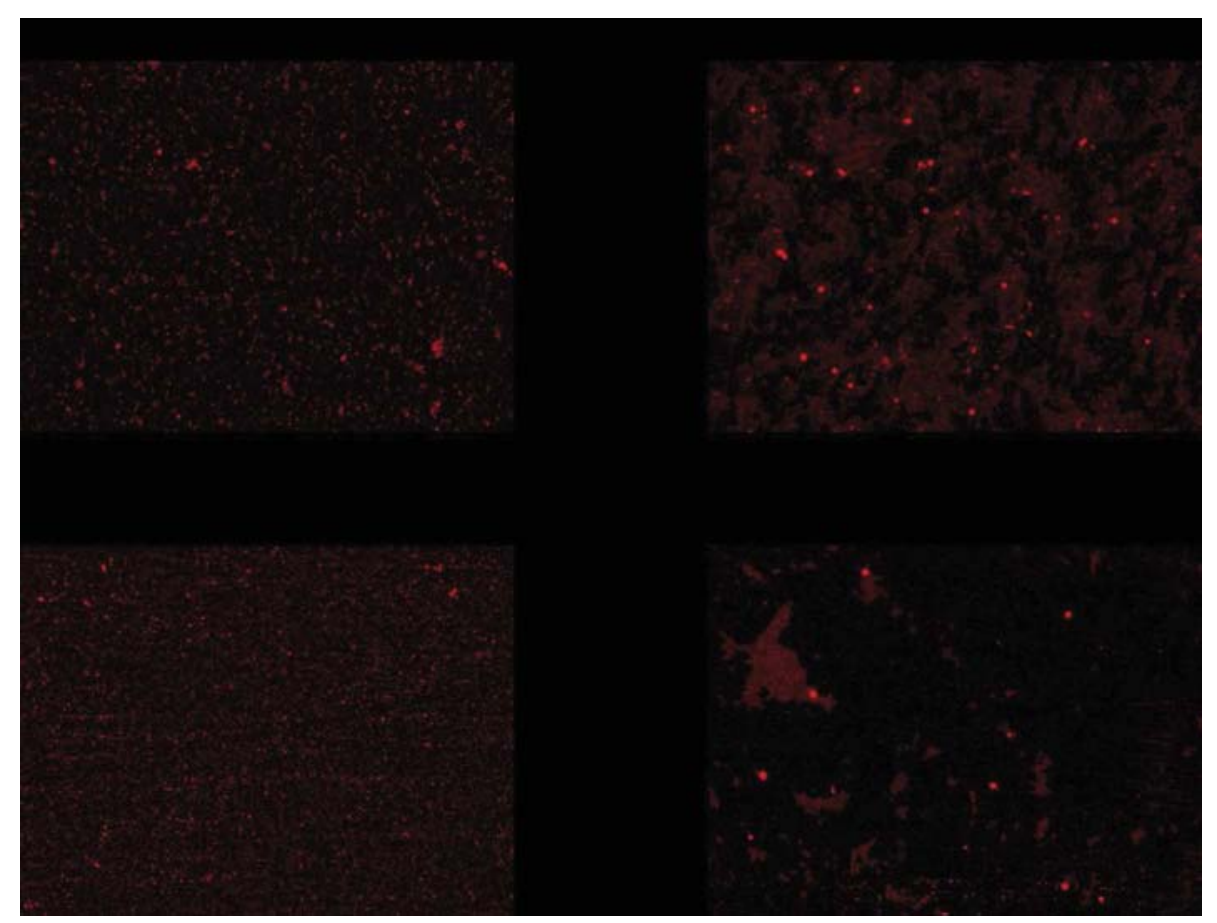

Fig. 3. Epifluorescent microscopy pictures of the monospecies biocathodes. Monospecies biocathodes were formed in synthetic seawater after 7 days of polarization at $-0.3 \mathrm{~V} / \mathrm{ECS}$ in synthetic seawater (1st test in Table 1). Biofilm coverage ratios were 15, 22, 25 and 7\% for Bacillus, Marinobacter, Pseudoalteromonas and Roseobacter, respectively.

investigations can progress. The synthetic seawater used here corresponded to the standard composition implemented in physical-chemistry studies to characterize the abiotic corrosion of materials in seawater. Consequently, it did not contain the micronutrients, vitamins and other possible traces of organic compounds that are present in natural seawater. The current densities obtained here in the "physicochemical" synthetic seawater show the interest of going ahead with the design of a "biological" synthetic seawater, which would be able to sustain full electro-activity of the seawater electroactive microbial strains. Further studies will aim at defining what micro-components, present in natural seawater, should be added into the composition of the "physicochemical" synthetic seawater to improve the biocathode performance in a synthetic medium.

The biocathodes were checked by cyclic voltammetry at different times during the chronoamperometries. All the monospecies biocathodes gave similar shapes of the current-potential curves, only the values of the current density were different. The best performance was around $0.8 \mathrm{~A} \mathrm{~m}^{-2}$ at $-0.6 \mathrm{~V} / \mathrm{SCE}$ with the Pseudoalteromonas strain (Fig. 2). The open circuit potential was around $-0.1 \mathrm{~V} / \mathrm{SCE}$ for most monospecies biocathodes and the biocatalytic effect started in the range from $-0.1 \mathrm{~V} / \mathrm{SCE}$ to $-0.3 \mathrm{~V} /$ SCE, as illustrated in Fig. 2 with two extreme examples. When the solution was stirred, the current-potential curve had an exponential form, characteristic of electron-transfer limited kinetics. Gentle stirring was consequently sufficient to suppress mass transfer limitation, showing that the electron transfer kinetics was not very efficient. As expected, bubbling air into the reactor shifted the curve to higher currents than stirring, because it ensured the solution was stirred and also increased the concentration of dissolved oxygen in the bulk.

\section{Monospecies vs. multispecies biofilms}

The performance of multispecies biocathodes that form spontaneously in seawater under identical operating conditions (stainless steel electrodes polarized at $-0.2 \mathrm{~V} / \mathrm{SCE}$ ) has already been reported in the literature (Bergel et al., 2005): open circuit potentials were around $+0.2 \mathrm{~V} / \mathrm{SCE}$ and current density reached $0.8 \mathrm{~A} \mathrm{~m}^{-2}$ at $-0.3 \mathrm{~V} / \mathrm{SCE}$ under aeration. In comparison, the monospecies biocathodes formed here gave lower catalytic performance. It was necessary to impose around $400 \mathrm{mV}$ lower potentials to obtain current densities of the same order of magnitude.

The low colonization of the electrode surface may be a first element of an explanation. Here, epifluorescence imaging showed scarce cells or small micro-colonies adhering to the electrode surface, while coverage ratios of the order of $60-65 \%$ were observed for seawater multispecies biofilms with average biofilm thickness around $20 \mu \mathrm{m}$ (Erable et al., 2010). Moreover, the presence of diverse microbial communities may also be required to reach higher currents. Microbial species not directly involved in the electron transfer pathway, may favor the colonization of the surface by the electroactive species.

Much research has been carried out in the domain of marine biocorrosion to explain the oxygen-reduction catalytic properties of seawater biofilms (Erable et al., 2012). It has pointed out a huge number of possible mechanisms, which can be roughly organized into three main groups:

i) direct catalysis by extracellular compounds that are excreted by the cells and retained against the material surface by the biofilm matrix: extracellular enzymes (Lai and Bergel, 2000; Faimali et al., 2011; Erable et al., 2012), hemin (Iken et al., 2008), or quinone-based compounds (Freguia et al., 2010) have, for instance, been suspected of playing this role;

ii) indirect catalysis mediated by metabolites, hydrogen peroxide (Landoulsi et al., 2008), or manganese oxide (Braughton et al., 2001);

iii) and miscellaneous mechanisms, such as local acidification inside the biofilm, modification of the oxide layer properties of stainless steels, influence of light, etc., which are less often mentioned. 
The emergence of MFC technology has suggested the possibility of direct electron transfer from the cathode to the metabolism of the cells (Rosenbaum et al., 2011), although this mechanism has not been demonstrated yet for oxygen reduction as far as we know. Going beyond the strict domain of seawater biofilms, a rather complex mechanism has been proposed recently for oxygenreducing biocathodes formed from wastewater. A synergistic role of sulphate reducing bacteria has been postulated with other bacteria, such as purple non-sulphur bacteria and spirochetes, including a cycling oxidation of sulphide to sulphate on the cathode (Cristiani et al., 2013b).

Marinobacter sp. belongs to the dominant class of GammaProteobacteria and has recently been identified as one of the only two genera that compose the microbial community of very efficient high salinity-tolerant bioanodes (Rousseau et al., 2014). The domain of reversible bioelectrodes has been approached by a few recent studies (Cheng et al., 2010; Strik et al., 2010; Blanchet et al., 2014). A few multispecies biofilms have proved able to catalyse the oxidation of acetate on an anode in anaerobic conditions, whereas they were able to catalyse the reduction of oxygen on a cathode when switched to aerobic conditions. These studies all implemented multispecies electrodes. Marinobacter sp. might be a suitable candidate for the establishment of a monospecies reversible electrode.

\section{Conclusions}

Monospecies biocathodes were established with Pseudoalteromonas sp., Marinobacter sp., Roseobacter sp. and Bacillus sp., which operated in natural seawater and in synthetic medium. This first success in designing seawater monospecies biocathodes was achieved through a new experimental procedure that included the preliminary immersion of the electrode in the cell culture.

\section{Acknowledgements}

The authors gratefully acknowledge Dr. M. Faimali from the Institute of Marine Sciences (ISMAR-CNR, Genoa, Italy). We thank Professor Berge (Faculty of Pharmacy, Toulouse University) for his help in the identification of the four bacterial isolates. This work was carried out in the framework of the "BioCathInox (ANR-GUIAAP-04)" project, supported by the French national research agency, ANR.

\section{References}

Bergel, A., Feron, D., Mollica, A., 2005. Catalysis of oxygen reduction in PEM fuel cell by seawater biofilm. Electrochem. Commun. 7, 900-904. http://dx.doi.org/ 10.1016/j.elecom.2005.06.006.

Blanchet, E., Pécastaings, S., Erable, B., Roques, C., Bergel, A., 2014. Protons accumulation during anodic phase turned to advantage for oxygen reduction during cathodic phase in reversible bioelectrodes. Bioresour. Technol. 173, 224-230. http://dx.doi.org/10.1016/j.biortech.2014.09.076.

Bonanni, P., David Schrott, G., Pablo Busalmen, J., 2012. A long way to the electrode: how do Geobacter cells transport their electrons? Biochem. Soc. Trans. 40, 1274-1279. http://dx.doi.org/10.1042/BST20120046.

Braughton, K.R., Lafond, R.L., Lewandowski, Z., 2001. The influence of environmental factors on the rate and extent of stainless steel ennoblement mediated by manganese-oxidizing biofilms. Biofouling 17, 241-251.

Cheng, K.Y., Ho, G., Cord-Ruwisch, R., 2010. Anodophilic biofilm catalyzes cathodic oxygen reduction. Environ. Sci. Technol. 44, 518-525. http://dx.doi.org/10.1021/ es9023833.

Cristiani, P., Carvalho, M.L., Guerrini, E., Daghio, M., Santoro, C., Li, B., 2013a. Cathodic and anodic biofilms in single chamber microbial fuel cells. Bioelectrochemistry 92, 6-13. http://dx.doi.org/10.1016/j.bioelechem.2013.01.005.

Cristiani, P., Franzetti, A., Gandolfi, I., Guerrini, E., Bestetti, G., 2013b. Bacterial DGGE fingerprints of biofilms on electrodes of membraneless microbial fuel cells. Int. Biodeterior. Biodegr. 84, 211-219. http://dx.doi.org/10.1016/ j.ibiod.2012.05.040
Erable, B., Feron, D., Bergel, A., 2012. Microbial catalysis of the oxygen reduction reaction for microbial fuel cells: a review. Chemsuschem 5, 975-987. http:// dx.doi.org/10.1002/cssc.201100836.

Erable, B., Vandecandelaere, I., Faimali, M., Delia, M.-L., Etcheverry, L., Vandamme, P., Bergel, A., 2010. Marine aerobic biofilm as biocathode catalyst. Bioelectrochemistry 78, 51-56. http://dx.doi.org/10.1016/ j.bioelechem.2009.06.006.

Faimali, M., Benedetti, A., Pavanello, G., Chelossi, E., Wrubl, F., Mollica, A., 2011. Evidence of enzymatic catalysis of oxygen reduction on stainless steels under marine biofilm. Biofouling 27, 375-384. http://dx.doi.org/10.1080/ 08927014.2011.576756.

Faimali, M., Chelossi, E., Pavanello, G., Benedetti, A., Vandecandelaere, I., De Vos, P., Vandamme, P., Mollica, A., 2010. Electrochemical activity and bacterial diversity of natural marine biofilm in laboratory closed-systems. Bioelectrochemistry 78 , 30-38. http://dx.doi.org/10.1016/j.bioelechem.2009.04.012.

Freguia, S., Tsujimura, S., Kano, K., 2010. Electron transfer pathways in microbial oxygen biocathodes. Electrochim. Acta 55, 813-818. http://dx.doi.org/10.1016/ j.electacta.2009.09.027.

Heip, C.H.R., Goosen, N.K., Herman, P.M.J., Kromkamp, J., Middelburg, J.J., Soetaert, K., 1995. Production and consumption of biological particles in temperate tidal estuaries. In: Ansell, A.D., Gibson, R.N., Barnes, M. (Eds.), Oceanography and Marine Biology - an Annual Review, vol. 33. U C L Press Ltd, London, pp. 1-149.

Holmes, D.E., Bond, D.R., O'Neill, R.A., Reimers, C.E., Tender, L.R., Lovley, D.R., 2004. Microbial communities associated with electrodes harvesting electricity from a variety of aquatic sediments. Microb. Ecol. 48, 178-190. http://dx.doi.org/ 10.1007/s00248-003-0004-4.

Iken, H., Etcheverry, L., Bergel, A., Basseguy, R., 2008. Local analysis of oxygen reduction catalysis by scanning vibrating electrode technique: a new approach to the study of biocorrosion. Electrochim. Acta 54, 60-65. http://dx.doi.org/ 10.1016/j.electacta.2008.02.120.

Lai, M.E., Bergel, A., 2000. Electrochemical reduction of oxygen on glassy carbon: catalysis by catalase. J. Electroanal. Chem. 494, 30-40. http://dx.doi.org/ 10.1016/S0022-0728(00)00307-7.

Landoulsi, J., El Kirat, K., Richard, C., Feron, D., Pulvin, S., 2008. Enzymatic approach in microbial-influenced corrosion: a review based on stainless steels in natural waters. Environ. Sci. Technol. 42, 2233-2242. http://dx.doi.org/10.1021/es071830g.

Lefebvre, O., Tan, Z., Kharkwal, S., Ng, H.Y., 2012. Effect of increasing anodic NaCl concentration on microbial fuel cell performance. Bioresour. Technol. 112, 336-340. http://dx.doi.org/10.1016/j.biortech.2012.02.048.

Liu, H., Cheng, S., Huang, L., Logan, B.E., 2008. Scale-Lip of membrane-free singlechamber microbial fuel cells. J. Power Sources 179, 274-279. http://dx.doi.org/ 10.1016/j.jpowsour.2007.12.120.

Logan, B.E., Rabaey, K., 2012. Conversion of wastes into bioelectricity and chemicals by using microbial electrochemical technologies. Science 337, 686-690. http:// dx.doi.org/10.1126/science.1217412.

Malvankar, N.S., Lovley, D.R., 2012. Microbial nanowires: a new paradigm for biological electron transfer and bioelectronics. Chemsuschem 5, 1039-1046. http://dx.doi.org/10.1002/cssc.201100733.

Mattila, K., Carpen, L., Hakkarainen, T., Salkinoja-Salonen, M.S., 1997. Biofilm development during ennoblement of stainless steel in Baltic Sea water: a microscopic study. Int. Biodeterior. Biodegr. 40, 1-10.

McCabe, K.M., Zhang, Y.H., Huang, B.L., Wagar, E.A., McCabe, E.R.B., 1999. Bacterial species identification after DNA amplification with a universal primer pair. Mol. Genet. Metab. 66, 205-211. http://dx.doi.org/10.1006/mgme.1998.2795.

Mollica, A., 1992. Biofilm and corrosion on active passive alloys in seawater. Int. Biodeterior. Biodegr. 29, 213-229. http://dx.doi.org/10.1016/0964-8305(92) 90045-P.

Pant, D., Van Bogaert, G., Diels, L., Vanbroekhoven, K., 2010. A review of the substrates used in microbial fuel cells (MFCs) for sustainable energy production. Bioresour. Technol. 101, 1533-1543. http://dx.doi.org/10.1016/ j.biortech.2009.10.017.

Parot, S., Vandecandelaere, I., Cournet, A., Delia, M.-L., Vandamme, P., Berge, M., Rogues, C., Bergel, A., 2011. Catalysis of the electrochemical reduction of oxygen by bacteria isolated from electro-active biofilms formed in seawater. Bioresour. Technol. 102, 304-311. http://dx.doi.org/10.1016/j.biortech.2010.06.157.

Pocaznoi, D., Erable, B., Etcheverry, L., Delia, M.-L., Bergel, A., 2012. Towards an engineering-oriented strategy for building microbial anodes for microbial fuel cells. Phys. Chem. Chem. Phys. 14, 13332-13343. http://dx.doi.org/10.1039/ c2cp42571h.

Rhoads, A., Beyenal, H., Lewandowski, Z., 2005. Microbial fuel cell using anaerobic respiration as an anodic reaction and biomineralized manganese as a cathodic reactant. Environ. Sci. Technol. 39, 4666-4671. http://dx.doi.org/10.1021/ es048386r.

Rimboud, M., Pocaznoi, D., Erable, B., Bergel, A., 2014. Electroanalysis of microbial anodes for bioelectrochemical systems: basics, progress and perspectives. Phys. Chem. Chem. Phys. 16, 16349-16366. http://dx.doi.org/10.1039/c4cp01698j.

Rosenbaum, M., Aulenta, F., Villano, M., Angenent, L.T., 2011. Cathodes as electron donors for microbial metabolism: which extracellular electron transfer mechanisms are involved? Bioresour. Technol. 102, 324-333. http://dx.doi.org/ 10.1016/j.biortech.2010.07.008.

Rousseau, R., Dominguez-Benetton, X., Delia, M.-L., Bergel, A., 2013. Microbial bioanodes with high salinity tolerance for microbial fuel cells and microbial electrolysis cells. Electrochem. Commun. 33, 1-4. http://dx.doi.org/10.1016/ j.elecom.2013.04.002. 
Rousseau, R., Santaella, C., Achouak, W., Godon, J.-J., Bonnafous, A., Bergel, A., Délia, M.-L., 2014. Correlation of the electrochemical kinetics of high-salinitytolerant bioanodes with the structure and microbial composition of the biofilm. ChemElectroChem 1, 1966-1975. http://dx.doi.org/10.1002/celc.201402153.

Shi, X.M., Avci, R., Lewandowski, Z., 2002. Electrochemistry of passive metals modified by manganese oxides deposited by Leptothrix discophora: two-step model verified by ToF-SIMS. Corros. Sci. 44, 1027-1045. http://dx.doi.org/ 10.1016/S0010-938X(01)00104-4.
Strik, D.P.B.T.B., Hamelers, H.V.M., Buisman, C.J.N., 2010. Solar energy powered microbial fuel cell with a reversible bioelectrode. Environ. Sci. Technol. 44, 532-537. http://dx.doi.org/10.1021/es902435v.

Vandecandelaere, I., Nercessian, O., Faimali, M., Segaert, E., Mollica, A., Achouak, W. De Vos, P., Vandamme, P., 2010. Bacterial diversity of the cultivable fraction of a marine electroactive biofilm. Bioelectrochemistry 78, 62-66. http://dx.doi.org/ 10.1016/j.bioelechem.2009.07.004. 